\section{Quality assessment of Zeus faber (Peter's fish) ovaries regularly commercialized for human consumption}

Filippo Giarratana, Graziella Ziino, Valerio D'Andrea, Antonio Panebianco, Alessandro Giuffrida

Department of Veterinary Science, University of Messina, Italy

\begin{abstract}
In the last few years, the consumption of fish eggs has increased rapidly, finding widespread use also in mass catering. This increase has involved also those of the Peter's fish (Zeus faber). Females of this species, by their reproductive characteristics, have highly developed gonads in different periods of the year, making the raw material easy to find. The aim of the present study was to perform a quality assessment of Zeus faber ovaries regularly commercialized for human consumption. A total number of 34 samples, divided in fresh (11) and frozen (23), were processed for microbiological characterization, parasitological and histological evaluations. Fresh and frozen samples have significant $(\mathrm{P}<0.01)$ differences in total bacterial charge, with values of $4.75 \pm 0.5 \mathrm{Log} C F U / g$ and $3.65 \pm 0.7 \mathrm{Log}$ $\mathrm{CFU} / \mathrm{g}$ respectively. The mean value of Enterobacteriaceae was $2.58 \pm 0.7 \mathrm{Log}$ $\mathrm{CFU} / \mathrm{g}$ in fresh products, while $52.17 \%$ (12) of frozen samples reported loads of $<1 \mathrm{Log}$ $\mathrm{CFU} / \mathrm{g}$. No Salmonella spp. and Listeria monocytogenes were found. Aeromonas spp. was detected in two frozen sample (with loads of 2.2 and $<1 \mathrm{Log} C F U / g$ ) and in 5 fresh ovaries with value ranged from 1.70 to $3.48 \mathrm{Log} \mathrm{CFU} / \mathrm{g}$. Vibrio spp. was found in $4(36.36 \%)$ and $3(13.04 \%)$ of fresh and frozen samples respectively, with loads always $<1$ Log CFU/g. All 31 Vibrio strains isolated, were identified as Vibrio alginolyticus, and $61.29 \%$ (19) of them was positive for the ToxRS factor and $6.45 \%$ (2) for ToxR. The $47.06 \%$ (16) of total samples showed infestations by larvae of Anisakis Type 1 in the serous and inside the ovary. In this last case, histologically it was found to be free larvae. This study attested satisfactory hygiene conditions for Zeus faber ovaries currently marked for human consumption. The presence of potentially pathogenic strains of $V$. alginolyticus and Aeromonas spp., but above all the frequent infestation by Anisakis larvae, represent a potentially hazard for the consumer.
\end{abstract}

\section{Introduction}

The use and conservation of fish gonads as foodstuff dates back more than three thousand years ago in Sardinia as gift of the Phoenicians. Today, they are considered a valuable material and sometimes, as regards of some fishes, even difficult to find. Both female and male gonads are usually considered edible foods. Male gonads are constituted by fish testes and are commonly known as latti or lattumi (Palese and Palese, 1992). Female gonads have a wider distribution and are commercialized as fresh products but also salted, dried, smoked and marinated. Depending on the source, the local traditions and the preservation technologies, gonads are processed and then commercialized like ovarian sack (i.e. Bottarga) or as eggs, without the serous coating (caviar, salmon eggs, lumpfish roes, etc.) (Giuffrida and Panebianco, 2008). In the last few years, the consumption of fish eggs has increased rapidly, finding widespread use also in mass catering (EUROSTAT, 2017).

This increase has involved also those of the Peter's fish (Zeus faber). Female of this species, thanks to their reproductive characteristics, show highly developed gonads in different periods of the year (Fulton, 1898). Moreover, this species is widespread all over Mediterranean areas, making the raw material easy to find. Several studies reported microbiological characterization of different fish roe product, revealing the presence, in some occasion, of food borne pathogens (Altug and Bayrak 2003; Boǐko et al., 2004; Oeleker et al., 2015; Razavilar and Rezvani, 2004; Voidarou et al., 2011). No information on Peter's fish roe microbiology are, instead, available. Furthermore, Zeus faber is often subjected to Anisakidae colonization that can be found frequently in ovaries (Pekmezci et al., 2014; Yardimci et al., 2014). For all these reasons, the aim of the present study was to perform a quality assessment of Zeus faber ovaries regularly commercialized for human consumption.

\section{Materials and Methods}

\section{Sample collection and macroscopic observations}

A total number of 34 Zeus faber ovaries (11 fresh and 23 frozen samples) were collected from local market of Mazara del Vallo in a period from October to May. Fishes were caught in FAO area 37.1.2 and 37.2.2, by the trawl fleet of Mazara del Vallo (Sicily, Italy). Mazara del Vallo is widely considered to be the most important
Correspondence: Filippo Giarratana, Department of Veterinary Science, University of Messina, Polo Universitario dell'Annunziata, 98168 Messina, Italy. Tel.: +39.090.3503768.

E-mail: fgiarratana@unime.it

Key words: Zeus faber; fish eggs; Anisakis; microbiology; histology.

Contributions: the authors contributed equally. Conflict of interest: the authors declare no potential conflict of interest.

Funding: none.

Received for publication: 16 August 2017.

Revision received: 6 November 2017.

Accepted for publication: 7 November 2017

This work is licensed under a Creative Commons Attribution-NonCommercial 4.0 International License (CC BY-NC 4.0).

CCopyright F. Giarratana et al., 2018

Licensee PAGEPress, Italy

Italian Journal of Food Safety 2018; 7:6997

doi:10.4081/ijfs.2018.6997

fishing center in Italy and contributes for more than $3 / 4$ to the production and turnover of the national trawl fleet (ISTAT data).

Fresh ovaries were transported to our laboratory under refrigerated conditions $\left(4^{\circ} \mathrm{C}\right)$ and processed within $24 \mathrm{~h}$ from their arrival. Frozen samples were, instead, primarily thawed at $4^{\circ} \mathrm{C}$ for $24 \mathrm{~h}$. Each sample was carefully examined for the presumptive presence of parasites. All parasites were examined under stereoscopic microscope (Leica M 205C), and the belonging to the Anisakis genus was made according to guidelines proposed by Murata et al. (2011).

\section{Microscopic analysis}

Portions of each sample were fixed in buffered formalin $(10 \%)$, embedded in paraffin, and sliced into $5-\mu \mathrm{m}$ sections. Sections were stained using hematoxylineosin (HE) and trichrome Masson. Stained sections were examined using light microscopy (Leica DM 4000B).

\section{Microbiological analysis}

Each sample was processed for the count of: i) Aerobic mesophilic bacteria (AMB) according to UNI EN ISO 4833:2004; ii) Enterobacteriaceae according to UNI EN ISO 21528-2:2004; iii) Vibrio spp. on Thiosulphate Citrate Bile Salt Sucrose Agar (TCBS Oxoid, Italy), with $3 \% \mathrm{NaCl}$, incubated at $37^{\circ} \mathrm{C}$ for $24 \mathrm{~h}$; 
iv) Aeromonas spp. in Glutamate Starch Phenol Red Agar (GSP) with Ampicillin Selective Supplement (Merk, Italy), incubated at $30^{\circ} \mathrm{C}$ for $24 \mathrm{~h}$.

The detection of the following parameter was also conducted: i) Vibrio spp. with a preliminary enrichment on Phosphate Buffer Saline (PBS) at $30^{\circ} \mathrm{C}$ for $24 \mathrm{~h}$, then spread on TCBS, with $3 \% \mathrm{NaCl}$ and incubated at $37^{\circ} \mathrm{C}$ for $24 \mathrm{~h}$; ii) Aeromonas spp. with a preliminary enrichment on PBS at $30^{\circ} \mathrm{C}$ for $24 \mathrm{~h}$, then spread on in GSP with Ampicillin and incubated at $30^{\circ} \mathrm{C}$ for $24 \mathrm{~h}$; iii) Listeria monocytogenes detection according to UNI EN ISO 11290-1: 2005; iv) Salmonella spp. detection according to UNI EN ISO 6579: 2002.

\section{Vibrio identification: biochemical protocol}

Suspected alophilic vibrios were confirmed to genus level to according to biochemical protocol suggested by Ottaviani et al. (2003). Isolated colonies growth on TCBS, were tested for Gram stains, Ossidase test, vibriostatic factor O/129 (150 mg, Oxoid) and growth on Kliger Iron Agar (KIA, Biolife, Italy). All the strains that resulted belonging to Vibrio spp. were, then, confirmed by molecular methods.

\section{Vibrio identification: multiplex PCR assay}

For DNA extraction $1 \mathrm{~mL}$ of broth culture was centrifuged at $12.000 \mathrm{rpm}$ for 5 min; the pellet was re-suspended in $1 \mathrm{~mL}$ of sterile distilled water, boiled for $5 \mathrm{~min}$, and centrifuged again. The supernatant was stored at $20^{\circ} \mathrm{C}$ until use. DNA was quantified by means of a spectrophotometer (SmartSpec Plus, Bio-Rad, Milan, Italy). For Vibrio genus identification specific gene rpoA primers were employed, according to La Neve et al. (2006) and Dalmasso et al. (2009). Confirmed strains belonging to Vibrio genus were selected for further identification at species level. For $V$. alginolyticus, and $V$. parahaemolyticus identification, were employed specific primers encoding a collagenase gene portion, as suggested by Di Pinto et al. (2005). Primers for the screening of pathogenic factors toxR and toxRS were also added to the PCR mix as reported by Xie et al. (2005).

Multiplex PCR mix consisted in a total volume of $50 \mathrm{~mL}$ containing $5 \mathrm{~mL}$ of Buffer 10X, $200 \mathrm{mmol}$ of each dNTPs, $1.5 \mathrm{mmol}$ of $\mathrm{MgCl}_{2}, 100 \mathrm{nmol}$ of each primer, $1 \mathrm{~mL}$ of DNA template and $1 \mathrm{U}$ of Platinum Taq DNA Polymerase (Invitrogen).

\section{pH determination}

The $\mathrm{pH}$ of each sample was measured at room temperature with a $\mathrm{pH}$ meter HI90023CW (Hanna Instruments, Italy) equipped with a Mettler Toledo electrode (InLab 427) after homogenizing $3 \mathrm{~g}$ of sample in $27 \mathrm{~mL}$ distilled water for $10 \mathrm{~s}$ at 1300 rpm with an Ultra-Turrax T25 macevator (Janke \& Kunkel, Staufen, Germany). Each value was the mean of three replicates.

\section{Data analysis}

A t-Test was performed in order to evaluate significative differences in our results among the samples and between fresh and frozen products (XLSTAT, Microsoft Excel, Addinsoft). Significance level was assumed as $\mathrm{P}<0.01$. Microbiological charges were converted in Log CFU/g for a better expression of results.

\section{Results and Discussion}

\section{Microbiological results}

Table 1 shows mean values for each microbiological parameter. The mean values for AMC and Enterobacteriaceae were $3.94 \pm 0.5 \mathrm{Log} \mathrm{CFU} / \mathrm{g}$ and $1.30 \pm 1.2 \mathrm{Log}$ $\mathrm{CFU} / \mathrm{g}$ respectively. Fresh and frozen samples have significant $(\mathrm{P}<0.01)$ differences in $\mathrm{AMC}$, with mean values of $4.75 \pm 0.5 \mathrm{log}$ $\mathrm{CFU} / \mathrm{g}$ and $3.65 \pm 0.7 \mathrm{log} \mathrm{CFU} / \mathrm{g}$ respectively. In fresh ovaries, AMC oscillated from 3.65 to $5.17 \mathrm{Log} \mathrm{CFU} / \mathrm{g}$, while, in frozen samples ranged from 1.74 to $4.60 \mathrm{Log}$ $\mathrm{CFU} / \mathrm{g}$. Also for Enterobacteriaceae loads, significant differences $(\mathrm{P}<0.01)$ were observed between fresh and frozen products. In fresh products Enterobacteriaceae charges ranged from 1.17 to $3.43 \mathrm{Log}$ $\mathrm{CFU} / \mathrm{g}$, while $52.17 \%$ (12) of frozen samples reported Enterobacteriaceae loads $<1$ Log CFU/g.

Considering bacteriological hygiene indicators (AMC and Enterobacteriaceae), Zeus faber ovaries presented an overall satisfactory condition even as fresh product stored at refrigeration temperatures (Altug and Bayrak 2003; Bő̌ko et al., 2004; Oeleker et al., 2015; Razavilar and Rezvani, 2004; Voidarou et al., 2011).

The only microbiological concern may be related to pathogen detection. No Salmonella spp. and Listeria monocyto- genes were found. Otherwise, Aeromonas spp. and Vibrio spp. were detected in several samples of Zeus faber ovaries. Aeromonas strains have a significative incidence in marine environment all over Europe and were frequently detected in fishery product, including fish eggs (Davies et al., 2001; Hänninen et al., 1997; Hansen and Olafsen, 1989; Muscolino et al.; 2014). Bacteria belonging to Aeromonas genus may be, also, responsible of gastro-enteric diseases outbreaks in humans, thanks to the production of enterotoxins, cytotoxins and haemolysins (Deodhar et al., 1991; Kirov, 1993). For all these reasons, they could represent a microbiological hazard for the consumer.

In our study, Aeromonas spp. was found in seven samples: two in frozen and five in fresh samples. The two positive frozen samples, were characterized by loads of $2.2 \mathrm{Log}$ $\mathrm{CFU} / \mathrm{g}$ and $<100 \mathrm{CFU} / \mathrm{g}$ respectively. In fresh ovaries, instead, Aeromonas spp was reported in $45.45 \%$ (5) of samples with loads ranging from 2.0 to $3.0 \mathrm{Log} \mathrm{CFU} / \mathrm{g}$. However, Aeromonas spp. mean loads revealed no significative difference $(\mathrm{P}>0.01)$ between fresh and frozen samples (Table 1). Considering its psychrophilic behavior, its tolerance and survival at frozen temperatures as well as its stress resistant variants, this study confirms Aeromonas spp. as potential microbiological hazard in Zeus faber ovaries intended for consumption (Castro-Escarpulli et al., 2003; Giuffrida et al., 2010).

Vibrio spp. was detected in the $36.36 \%$ (4) and $13.04 \%$ (3) of fresh and frozen samples respectively, but always with loads $<1$ Log CFU/g.

A total number of 31 suspected Vibrio spp. strains (14 from fresh and 17 from frozen samples) were isolated from TCBS with $3 \% \mathrm{NaCl}$. All suspected strains were confirmed as belonging to Vibrio spp., resulted positive for biochemical test and for molecular identification at genus level $(\mathrm{rpoA}+)$. Their presence in frozen samples, confirmed the remarkable resistance of halophilic Vibrio at freezing temperatures (Bang and Drake, 2002; Johnston and Brown, 2002). Multiplex PCR analysis

Table 1. Mean values \pm standard deviation expressed in $\log \mathrm{CFU} / \mathrm{g}$, of microbiological loads.

\begin{tabular}{lccc} 
& \multicolumn{1}{c}{ AMIB } & Enterobacteriaceac & Aeromonas spp. \\
Fresh & $4.75 \pm 0.5^{\mathrm{a}}(11 / 11)$ & $2.58 \pm 0.7^{\mathrm{a}}(11 / 11)$ & $1.09 \pm 1.3^{\mathrm{a}}(5 / 11)$ \\
Frozen & $3.65 \pm 0.7^{\mathrm{b}}(23 / 23)$ & $0.58 \pm 0.7^{\mathrm{b}}(11 / 23)$ & $0.09 \pm 0.4^{\mathrm{a}}(1 / 23)$ \\
\hline Total & $3.94 \pm 0.8(34 / 34)$ & $1.30 \pm 1.2(22 / 34)$ & $0.42 \pm 0.9(6 / 34)$ \\
\hline
\end{tabular}

a,bifferent letters represent significative differences $(\mathrm{P}<0.01)$, (positive samples/total samples). 
revealed that all 31 strains isolated were $V$. alginolyticus.

This bacteria is often found in Italian marine coastal environments and sea products (Dumontet et al., 2000; Panebianco et al., 2011; Narracci et al., 2013; Ziino et al., 2010; Ziino et al., 2014). It is also, widely spread all over the world, and usually has the highest prevalence in Vibrio communities (Schets et al., 2010; Jones et al., 2013). $V$. alginolyticus pathogenic potential in humans is well recognized, causing various infections and inflammation patterns (Schmidt et al., 1979). It raised great importance as emergent foodborne pathogen, responsible for several cases of gastroenteritis linked to the consumption of fish products (Mustapha et al., 2013). Moreover, in immune-compromised subjects, serious extra-intestinal infections, such as septic shock, have been reported as consequence of consumption of seafood contaminated by V. alginolyticus (Dong-Young et al., 2008). ToxRS and ToxR pathogenic factors encode trans-membrane proteins that mediate the regulation of the virulence gene expression in several pathogenic Vibrio strains, including V. alginolyticus (Das et al., 2016). These factors are frequently investigated for a better characterization of bacterial pathogenic potential (Fu et al., 2016). Moreover, ToxR is widely proposed for the specie identification and phylogenetic analyses (Montieri et al., 2010). Considering all the $31 \mathrm{~V}$. alginolyticus strains, $61.5 \%$ carried the ToxRS factor and in lower percentage $(6.5 \%)$ the ToxR gene. In particular, among the 14 strains isolated from fresh samples, 12 $(85.7 \%)$ were ToxR positive and 2 (14.3\%) carried the ToxRS pathogenic factor. Otherwise, among the 17 strains isolated from frozen samples, 7 (41.2\%) were ToxR positive but no ToxRS positive strains were found. It was asserted that ToxR may assist $V$. alginolyticus in host target cells adhesion, which is crucial step for the initiation of the infection (Chang et al., 2002). As reported by previous studies, fish roe represent an ideal setting for Vibrio colonization (Voidarou et al., 2011). Our results highlight the role of Zeus faber ovaries as source of $V$. alginolyticus pathogenic strains, which could be potentially implicated in foodborne disease episodes.

\section{pH results}

The $\mathrm{pH}$ mean values was $6.32 \pm 0.2$ for fresh ovaries and $6.22 \pm 0.3$ for frozen products with no significant differences $(\mathrm{P}>0.01)$ between the two kind of samples.

\section{Macroscopic and microscopic analy- sis results}

The $47.05 \%$ (16) of total samples revealed parasitic infestation by presumptive nematode, confirmed by stereomicroscopic observation as Anisakis larvae type I. Specifically, larvae were found in 16 ovaries: $45.45 \%$ (5) and (11) $47.82 \%$ of fresh and frozen samples respectively. Various levels of infestation were observed: from isolated larvae to a massive infestation, in which nematodes were bunchshaped aggregated (Figure 1).

The histological investigation showed the presence of various patterns, ascribable to different gonadic development stages (Abou-Seedo et al., 2003; Macrì et al., 2011). Specifically, in some analyzed ovaries, a primary stage of oocyte growth (Previtellogenic stage) was observed (Figure 2), while in other samples a second-

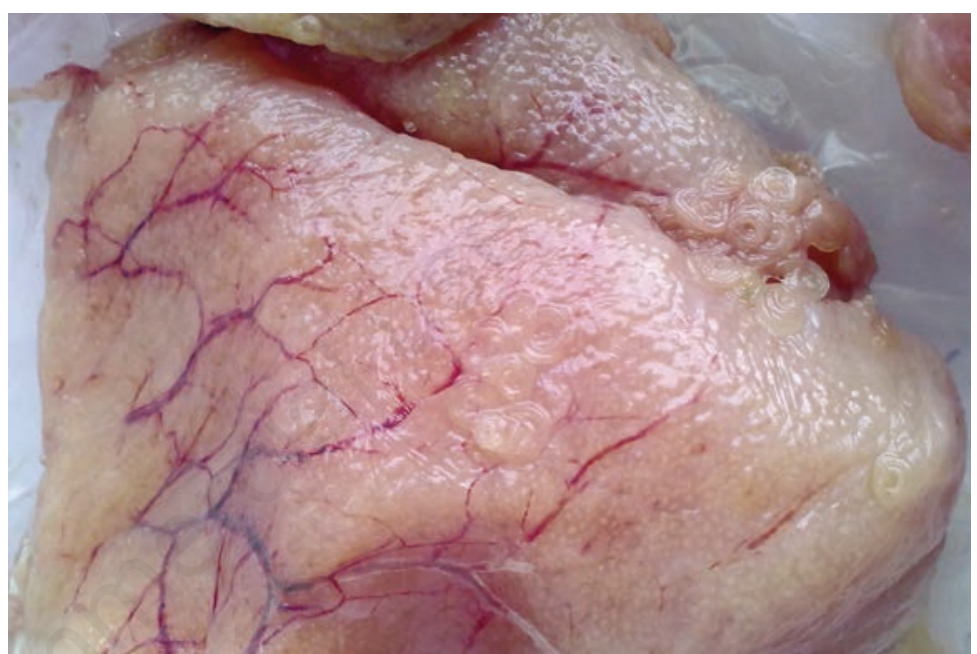

Figure 1. Massive infestation of Anisakis larvae type $I$ in fresh sample of Zeus faber ovaries.

Figure 2. Previtellogenic stage: a primary stage of oocyte growth in fresh sample of Zeus ary stage of oocyte maturation (Vitellogenic stage) was predominant (Figure 3), with no relation to season or area of fishing.

In samples infested by Anisakis larvae, parasites were found encysted on the serosa, and were not observed tissue and cellular reactions (Figure 4). Only in two cases, however, it was possible to observe parasites inside the gonads, not surrounded by any inflammatory reaction (Figure 5). Our results confirm the parasitological risk due to the consumption of Zeus faber ovaries. Anisakis larvae detection deserve great attention, as the nematode have been also observed in the depth of the gonads. The lack of connective capsule and inflammatory response around the parasites, are consequences of larvae tissue mobilization,

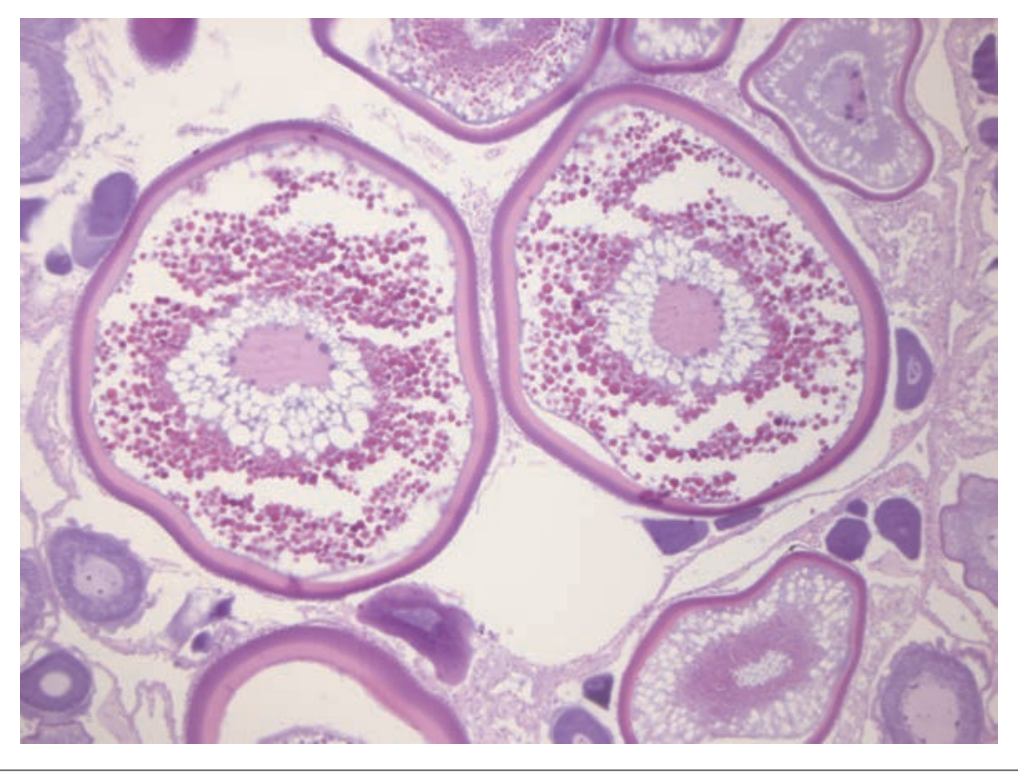

faber ovaries.

ovaries. 


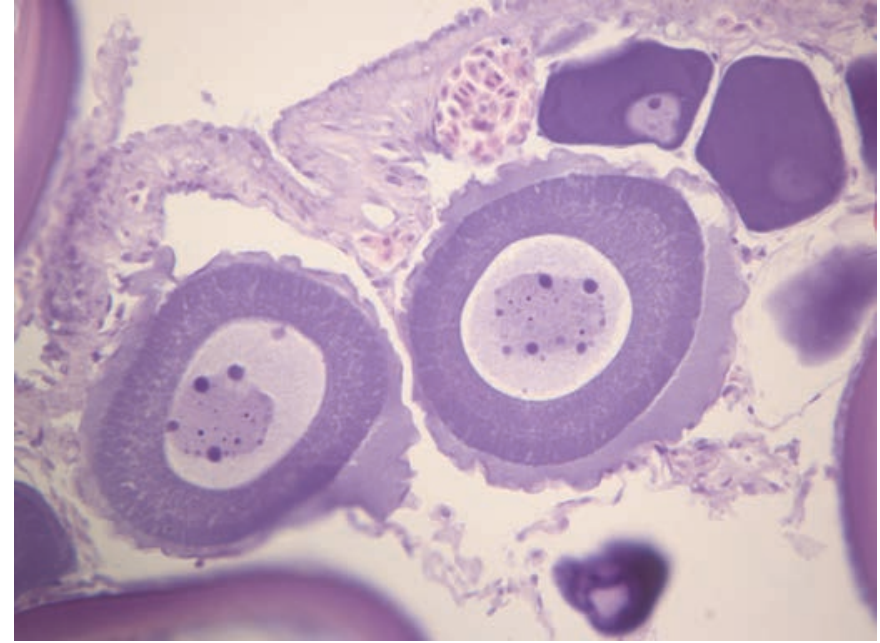

Figure 3. Vitellogenic stage: a secondary stage of oocyte maturation in fresh sample of Zeus faber ovaries.

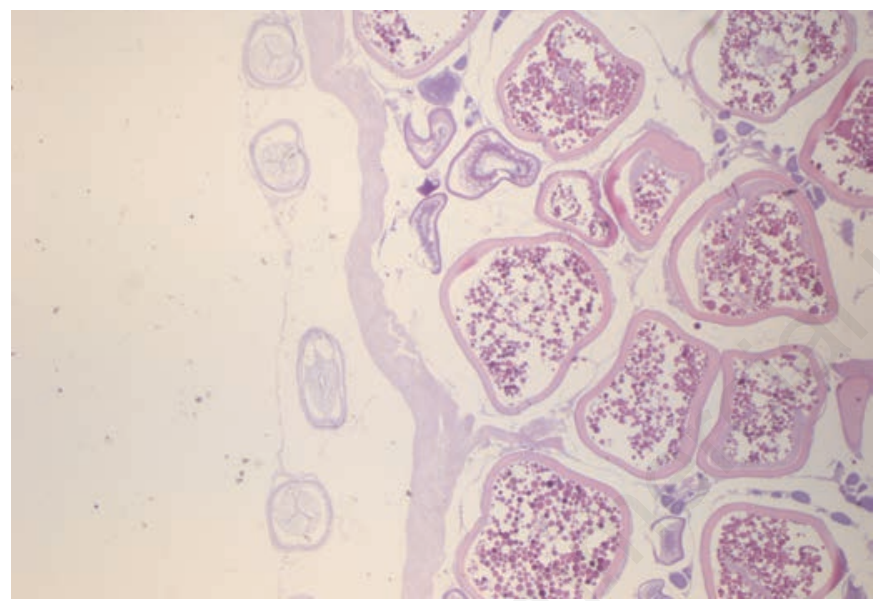

Figure 4. Presence of Anisakis larvae type I encysted on the serosa, without tissue and cellular reactions, in fresh sample of Zeus faber ovaries.

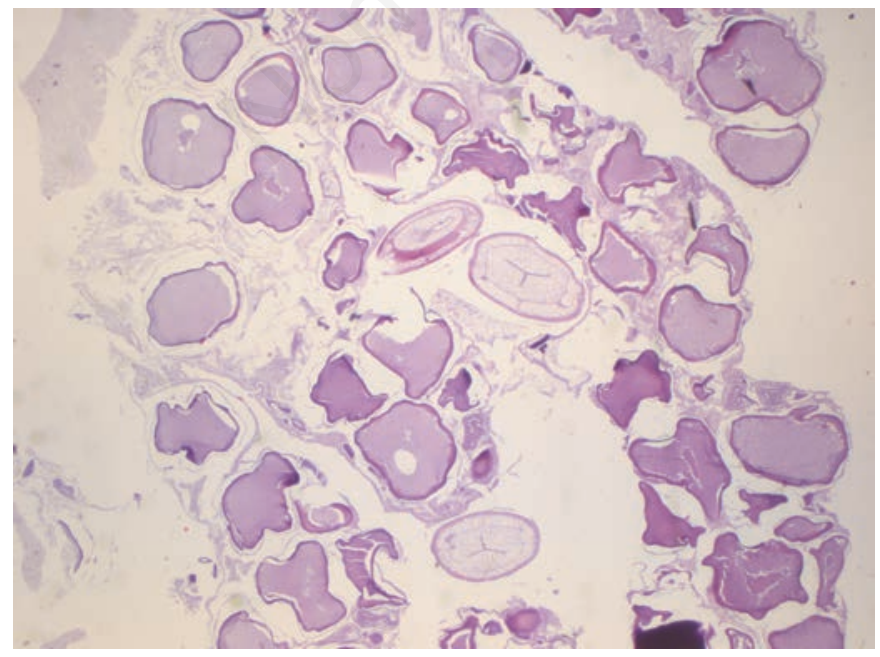

Figure 5. Presence of Anisakis larvae type I inside the gonads, not surrounded by any inflammatory reaction, in frozen sample of Zeus faber ovaries. Aspect of structural damage in frozen samples: oocytes coerced, with irregular contours, fragmented and wellspaced. The cytoplasm lost its characteristic granular appearance and are evident intracytoplasmic vacuoles. searching for favorable conditions after the fish death. In these cases, Anisakis could be unnoticed to a superficial inspection, especially if a moderate infestation occur. However, it would, still, represent a risk for the consumer as thermal shock is not sufficient to avoid possible allergic reaction in sensitive subjects, caused by allergens resistant to high temperatures and freezing conditions (Audicana and Kennedy, 2008; Speciale et al., 2017).

In frozen samples, other microscopic findings are the damage related to the presence of intra and extra-cytoplasmic ice crystals. During thawing process, ice particles damaged the oocyte cell wall, causing the loss of cellular content. In particular, oocytes appeared coerced, with irregular contours, fragmented and well spaced. The cytoplasm lost its characteristic granular appearance, becoming uniformly acidophilus and, sometimes, voluminous intracytoplasmic vacuoles were observed (Figure 5). As reported in previous study microscopic analysis resulted a valid means to discriminate fresh products from those thawed (Meistro et al., 2016; Muscolino et al., 2012).

\section{Conclusions}

In conclusion, Zeus faber fish ovaries showed more than satisfactory hygiene conditions. The only microbiological concern was related to the presence of potentially pathogenic strains of $V$. alginolyticus and Aeromonas spp.. However, microbiological hazard can be reduced by adequate cooking and the prevention of cross-contamination. In relation to the presence of Anisakis larvae, only an appropriated consumer information seems the most important measure to prevent allergic manifestations, beside an efficient thermal treatment or similar strategies in order to inactivate nematodes (Anastasio et al., 2015; Giarratana et al., 2012; Giarratana et al., 2014; Giarratana et al., 2015; Giarratana et al., 2017a; Giarratana et al., 2017b; Valero et al., 2015).

\section{References}

Abou-Seedo F, Dadzie S, Al-Kanaan KA, 2003. Histology of ovarian development and maturity stages in the yellowfin seabream Acanthopagrus latus (Teleostei: Sparidae) (Hottuyn, 1782) 
reared in cages. Kuwait J Sci Engin 30

Altug G, Bayrak Y. 2003. Microbiological analysis of caviar from Russia and Iran. Food Microbiol 20:83-6.

Anastasio A, Smaldone G, Cacace D, Marrone R, Lo Voi A, Santoro M, Cringoli G, Pozio E, 2015. Inactivation of Anisakis pegreffii larvae in anchovies (Engraulis encrasicolus) by salting and quality assessment of finished product. Food Control 64:115-9.

Audicana MT, Kennedy MW, 2008. Anisakis simplex: from obscure infectious worm to inducer of immune hypersensitivity. Clin Microbiol Rev 21:360-79.

Bang W, Drake MA, 2002. Resistance of cold-and starvation-stressed Vibrio vulnificus to heat and freeze-thaw exposure. J Food Protect 65:975-80.

Boı̌ko AV, Pogorelova NP, Zhuravleva LA, Lartseva LV, 1993. Microbial colonization of the caviar of the sturgeon fishes. Gigiena i sanitariia 11:30-1.

Castro-Escarpulli G, Figueras MJ, Aguilera-Arreola G, Soler L, Fernandez-Rendon E, Aparicio GO, Chacon MR, 2003. Characterisation of Aeromonas spp. isolated from frozen fish intended for human consumption in Mexico. Int J Food Microbiol 84:41-9.

Chang C, Qing-bai W, Zhu-Hong L, Jingjing Z, Xiao J, Hong-yan S, Chao-qun $H, 2012$. Characterization of role of the toxR gene in the physiology and pathogenicity of Vibrio alginolyticus. Antonie Van Leeuwenhoek 101:281-8.

Dalmasso A, La Neve F, Suffredini E, Croci L, Serracca L, Bottero MT, Civera T, 2009. Development of a PCR Assay Targeting the rpoA Gene for the Screening of Vibrio Genus. Food Analytical Methods 2:317-24.

Das SC, Kumar A, Kaushik P, Kumari S, 2016. Pathogenic and pandemic Vibrio parahaemolyticus detection in fish and shellfish isolates. Indian J Geo-Marine Sci 45:1195-8.

Davies AR, Capell C, Jehanno D, Nychas GJ, Kirby RM, 2001. Incidence of foodborne pathogens on European fish. Food Control 12:67-71.

Deodhar LP, Saraswathi K, Varudkar A, 1991. Aeromonas spp. and their association with human diarrheal disease. J Clin Microbiol 29:853-6.

Di Pinto A, Ciccarese G, Tantillo G, Catalano D, Forte VT, 2005. A collagenase-targeted multiplex PCR assay for identification of Vibrio alginolyticus, Vibrio cholerae, and Vibrio parahaemolyticus. J Food Protect 68:150-3.

Dong-Young L, Soo-Youn M, Sang-Oh L, HeeYoung Y, Hee-Joo L, Mi Suk L,
2008. Septic Shock due to Vibrio alginolyticus in a Cirrhotic Patient: The First Case in Korea. Yonsei Med J 49:329-32.

Dumontet S, Krovacek K, Svenson SB, Pasquale V, Baloda SB, Figliuolo G, 2000. Prevalence and diversity of Aeromonas and Vibrio spp. in coastal waters of Southern Italy. Comparative Immunol Microbiol Infect Dis 23:5372 .

EUROSTAT 2017. Production of fish eggs for human consumption from aquaculture (from 2008 onwards). EU open data portal. Available at: https:/data.europa.eu/euodp/data/datas et/IexxNEn7Uhv2yXTYlaog

Fu K, Li J, Wang Y, Liu J, Yan H, Shi L, Zhou L, 2016. An Innovative Method for Rapid Identification and Detection of Vibrio alginolyticus in Different Infection Models. Front Microbiol 7:651.

Fulton TW, 1898. The ovaries and ovarian eggs of the angler or frog-fish (Lophius piscatorius) and of the John Dory (Zeus faber). Ann Rep Fish Board Scotland 16:125-34.

Giarratana F, Giuffrida A, Gallo F, Ziino G, Panebianco A, 2012. Study of the Resistance Variability of Anisakis Larvae to Some Technological Stressors. In Veterinary Science, Springer Berlin Heidelberg, pp. 155159.

Giarratana F, Muscolino D, Beninati C, Giuffrida A, Panebianco A, 2014. Activity of Thymus vulgaris essential oil against Anisakis larvae. Experiment Parasitol 142: 7-10.

Giarratana F, Muscolino D, Panebianco F, Patania A, Benianti C, Ziino G, Giuffrida A, 2015. Activity of R (+) limonene against Anisakis larvae. Ital J Food Saf 4:5499.

Giarratana F, Muscolino D, Ziino G, Giuffrida A, Marotta SM, Lo Presti V, Chiofalo V, Panebianco A, 2017a. Activity of Tagetes minuta Linnaeus (Asteraceae) essential oil against L3 Anisakis larvae type 1. Asian Pacific J Trop Medicine 10:461-5.

Giarratana F, Muscolino D, Ziino G, Lo Presti V, Rao R, Chiofalo V, Giuffrida A, Panebianco A, 2017a. Activity of Catmint (Nepeta cataria) essential oil against Anisakis larvae. Trop Biomed 34:22-31.

Giarratana F, Panebianco F, Muscolino D, Beninati C, Ziino G, Giuffrida A, 2015. Effect of allyl isothiocyanate against Anisakis larvae during the anchovy marinating process. J Food Protect 78:767-71.
Giuffrida A, Panebianco A, 2008. Igiene e tecnologie dei prodotti della pesca freschi e trasformati,. In: Colavita G, ed. Igiene e tecnologia dei prodotti di origine animale. Le Point Vétérinarie Italie, Milano, Italy, pp 274-276.

Giuffrida A, Ziino G, Valenti D, Donato G, Panebianco A, 2007. Application of an interspecific competition model to predict the growth of Aeromonas hydrophila on fish surfaces during refrigerated storage. Archiv Lebensmittelhyg 58:136-41.

Hänninen ML, Oivanen P, Hirvelä-Koski V, 1997. Aeromonas species in fish, fisheggs, shrimp and freshwater. Int J Food Microbiol 34:17-26.

Hansen G H, Olafsen JA, 1989. Bacterial colonization of cod (Gadus morhua L.) and halibut (Hippoglossus hippoglossus) eggs in marine aquaculture. App Environment Microbiol 55:1435-46.

ISO 11290-1:1996. Microbiology of food and animal feeding stuffs. Horizontal method for the detection and enumeration of Listeria monocytogenes. Part 1: Detection method. International Standardization Organization Geneva, Switzerland.

ISO 21528-2:2004. Microbiology of the food chain - Horizontal methods for the detection and enumeration of Enterobacteriaceae Part 2: Colonycount method. International Standardization Organization Geneva, Switzerland.

ISO 4833-1:2013. Microbiology of the food chain. Horizontal method for the enumeration of microorganisms. Part 1: Colony count at 30 degrees $\mathrm{C}$ by the pour plate technique. International Standardization Organization Geneva, Switzerland.

ISO 6579:2002. Microbiology of food and animal feeding stuffs. Horizontal method for the detection of Salmonella spp. International Standardization Organization Geneva, Switzerland.

Johnston MD, Brown MH, 2002. An investigation into the changed physiological state of Vibrio bacteria as a survival mechanism in response to cold temperatures and studies on their sensitivity to heating and freezing. J App Microbiol 92:1066-77.

Jones EH, Feldman KA, Palmer A, Butler E, Blythe D, Mitchell CS, 2013. Vibrio infections and surveillance in Maryland, 2002-2008. Public Health Rep 128:537-45.

Kirov SM, 1993. The public health significance of Aeromonas spp. in foods. Int $\mathrm{J}$ Food Microbiol 20:179-98.

La Neve F, Pedonese F, Nuvoloni R, 
D’Ascenzi C, Dalmasso A, Civera T, 2006. Identificazione di Vibrioni di interesse sanitario in orate di allevamento mediante metodiche biomolecolari. LX Convegno Nazionale della Società Italiana delle Scienze Veterinarie, 432.

Macrì F, Rapisarda G, Marino G, De Majo M, Aiudi G, 2011. Use of Laparoscopy for the Evaluation of the Reproductive Status of Tench (Tinca tinca). Reprod Domestic Anim 46:130-3.

Meistro S, Pezzolato M, Muscolino D, Giarratana F, Baioni E, Panebianco A, Bozzetta E, 2016. Histology as a valid tool to differentiate fresh from frozenthawed marinated fish. J Food Protect 79:1457-9.

Montieri S, Suffredini E, Ciccozzi M, Croci L, 2010. Phylogenetic and evolutionary analysis of Vibrio parahaemolyticus and Vibrio alginolyticus isolates based on toxR gene sequence. New Microbiol 33:359-72.

Murata R, Suzuki J, Sadamasu K, Kai A, 2011. Morphological and molecular characterization of Anisakis larvae (Nematoda: Anisakidae) in Beryx splendens from Japanese waters. Parasitol Int 60:193-8.

Muscolino D, Giarratana F, Beninati C, Tornambene A, Panebianco A, Ziino G, 2014. Hygienic-sanitary evaluation of sushi and sashimi sold in Messina and Catania, Italy. Ital J Food Saf 3:134-6.

Muscolino D, Giarratana F, Giuffrida A, Panebianco A, 2012. Inspective investigation on swordfish (Xiphias gladius) frozen slices of commerce: anatomohistopatological findings. Czech J Food Sci 30:206-10.

Mustapha S, Mustapha EM, Nozha C, 2013. Vibrio alginolyticus: an emerging pathogen of food borne diseases. Int $\mathbf{J}$
Sci Tech 2:302-9.

Narracci M, Acquaviva MI, Cavallo RA, 2013. Mar Piccolo of Taranto: Vibrio biodiversity in ecotoxicology approach. Environ Sci Pollut Res Int 21:2378-85.

Oeleker K, Alter T, Kleer J, Pund RP, Gölz G, Hildebrandt G, Huehn S, 2015. Microbiological and chemical investigation of caviar at retail. $\mathrm{J}$ $\mathrm{V}$ e r b r a c h e r s c h u $\mathrm{z}$ Lebensmittelsicherheit 10:35-7.

Ottaviani D, Masini L, Bacchiocchi S, 2003. A biochemical protocol for the isolation and identification of current species of Vibrio in seafood. J App Bacteriol 95:1277-84.

Palese L, Palese A, 1992. Il controllo sanitaria e qualitative dei prodotti alimentari della pesca, vol. II. Ed. Piccin, Padova.

Panebianco A, Giuffrida A, Tasca D, Atanassova V, Ziino G, 2011. Shelf-life and microbiological properties of refrigerated sea urchin (Paracentrotus lividus) roe. Archiv Lebensmittelhygiene 62:11-5.

Pekmezci GZ, Onuk EE, Bolukbas CS, Yardimci B, Gurler AT, Acici M, Umur S, 2014. Molecular identification of Anisakis species (Nematoda: Anisakidae) from marine fishes collected in Turkish waters. Vet Parasitol 201:82-94.

Razavilar V, Rezvani S, 2004. Microbial risk assessment of Persian caviar during processing and cold storage. Dev Food Sci 42:441-6.

Schets FM, Van Den Berg HH, Rutjes SA, De Roda Husman AM, 2010. Pathogenic Vibrio species in dutch shellfish destined for direct human consumption. J Food Prot 73:734-8.

Schmidt U, Chmel H, Cobbs C, 1979. Vibrio alginolyticus infections in humans. J Clin Microbiol 10:666-8.
Speciale A, Trombetta D, Saija A, Panebianco A, Giarratana F, Ziino G, Minciullo PL, Cimino F, Gangemi S, 2017. Exposure to Anisakis extracts can induce inflammation on in vitro cultured human colonic cells. Parasitol Res 116:2471-7.

Valero A, Romero MC, Gòmez-Mateos M, Hierro I, Navarro MC, 2015. Natural products: Perspectives in the pharmacological treatment of gastrointestinal anisakiasis. Asian Pacific J Trop Medicine 8:612-7.

Voidarou C, Alexopoulos A, Plessas S, Noussias H, Stavropoulou E, Fotou K, Demertzi-Akrida K, 2011. Microbiological quality of grey-mullet roe. Anaerobe 17:273-5.

Xie ZY, Hu CQ, Chen C, Zhang LP, Ren $\mathrm{CH}, 2005$. Investigation of seven Vibrio virulence genes among Vibrio alginolyticus and Vibrio parahaemolyticus strains from the coastal mariculture systems in Guangdong, China. Lett App Microbiol 41:202-7.

Yardimci B, Pekmezci GZ, Onuk EE, 2014. Pathology and molecular identification of Anisakis pegreffii (Nematoda: Anisakidae) infection in the John Dory, Zeus faber (Linnaeus, 1758) caught in Mediterranean Sea. Ankara Universitesi Veteriner Fakultesi Dergisi 61:233-6.

Ziino G, Donato G, Giarratana F, Panebianco A, 2014. Bacteriological analysis to Arca noae (Linné, 1758) in the Sud of Italy: the first record of halophilic Vibrio. Cahiers Biol Marine 55:389-97.

Ziino G, Nibali V, Panebianco A, 2010. Bacteriological investigation on "Mauro" sold in Catania. Vet Res Comm 34:157-61. 